\title{
Perbandingan Pemeriksaan Leukosit Urine Segar Dengan Setelah 2 Jam Di Suhu Kamar
}

\author{
Nur Vita Purwaningsih ${ }^{1)}$, Rahma Widyastuti \\ Prodi DIII Teknologi Laboratorium Medik Universitas Muhammadiyah Surabaya \\ ${ }^{1)}$ vitasagi86@gmail.com
}

Tanggal Submit: 18 April 2018

Tanggal Review:

21 Mei 2018

Tanggal Publish

Online:

25 Mei 2018

\begin{abstract}
Background: Urinalysis is a parameter often requested by clinicians. The urinalysis parameters consist of macroscopic, microscopic or sedimental examination and urine chemistry examination. Urine examination is very important, especially in making the diagnosis. Procrastination delay results in errors in diagnosis and administration of drugs that lead to adverse outcomes of patients, analysis should be performed no later than 4 hours after sampling. Urine has a stability at room temperature ie for 1 hour, if urine is silenced long then the bacteria will multiply, so it can decompose $\mathrm{NH}_{3}$ (ammonia) which is alkaline. Under alkaline conditions, the $\mathrm{pH}$ in the urine will increase. This may affect the sediment component in the urine to rapid lysis so that the amount will be reduced General purpose of this study to determine the difference results of examination of fresh urine leukocytes compared after 2 hours at room temperature. Method: descriptive observasional with number of sample counted 20 sample. Result: Based on the test result, the positive percentage value in fresh urine is $100 \%$ and the positive percentage value in urine after 2 hours is $70 \%$. In the Wilcoxon statistical test obtained p-value $<0.001$ ( $>0.05)$. Conclusion: Based on the research that has been done then it can be concluded that there are differences in the results of fresh urine leukosit better than urine after 2 hours at room temperature.
\end{abstract}

Keywords: Leukocyte urine, Fresh urine, delay

\section{PENDAHULUAN}

Laboratorium yang baik
harus sesuai dengan
operasional prosedur
mengenai pengumpulan
untuk pengimen
Pedoman tersebut harus ditinjau
ulang oleh supervisor laboratorium.
Laboratorium juga perlu menetapkan

prosedur untuk penanganan spesimen dan prosedur untuk manajemen spesimen (penerimaan atau penolakan spesimen). Selalu ada tenaga kesehatan yang memiliki pengetahuan dan ketrampilan dalam upaya kesehatan yaitu, pasien, dokter dan paramedis atau perawat, petugas layanan transportasi, analis dan 
dokter laboratorium (Permenkes

Nomor 9, 2014).

Pemeriksaan urine ini sangat penting terutama dalam menegakkan diagnosis terhadap leukosituria. Penundaan pemeriksaan mengakibatkan kesalahan dalam diagnosis dan pemberian obat yang berujung merugikan pasien. Selain itu penundaan juga berpengaruh terhadap validitas hasil sedimen urine terutama leukosit yang merupakan petunjuk penting adanya infeksi saluran kemih.

Urinalisis merupakan parameter yang sering diminta oleh para klinisi. Parameter Urinalisis terdiri dari pemeriksaan makroskopik, mikroskopik atau sedimen dan pemeriksaan kimia urine. Tes mikroskopik untuk melihat eritrosit, leukosit, sel epitel, torak, bakteri, kristal, jamur dan parasit. Pemeriksaan makroskopik adalah untuk menilai warna, kejernihan dan bau. Analisis makroskopik secara fisik meliputi tes warna, kejernihan, bau, berat jenis dan pH. Analisis kimiawi meliputi tes protein, glukosa, keton, darah, bilirubin, urobilinogen, nitrit,dan lekosit esterase (Hardjoeno, 2007).
Seringkali sampel urine datang ke laboratarium sudah tidak segar lagi dan telah dikeluarkan beberapa jam sebelumnya. Klinisi sering mengalami kesulitan untuk tepat mengirim sampel urine sehingga hasil yang diharapkan banyak tidak sesuai dengan kondisi klinis pasien. Padahal tes urine dapat banyak memberikan informasi tentang disfungsi ginjal. Bahan tes yang terbaik adalah urine segar kurang dari 1 jam setelah dikeluarkan. Penundaan antara berkemih dan Urinalisis akan mengurangi validitas hasil, analisis harus dilakukan tidak lebih dari 4 jam setelah pengambilan sampel. Apabila dilakukan penundaan tes dalam 4 jam maka disimpan dalam lemari es pada suhu $2-4^{\circ} \mathrm{C}$. Urine yang dibiarkan dalam waktu lama pada suhu kamar akan menyebabkan perubahan pada urine. Unsur-unsur berbentuk di urine (sedimen) mulai mengalami kerusakan dalam 2 jam (Hardjoeno dan Rosalita, 2006).

Menurut Associaton of American Pediatrics (AAP, 2009) terdapat rentang yang luas pada laporan hasil Urinalisis. Hasil Urinalisis negatif tidak dapat 
menyingkirkan kemungkinan

diagnosis leukosituria, karena hasil

Urinalisis sangat dipengaruhi oleh

volume urine, kecepatan dan

lamanya urine diputar serta

keterampilan petugas. Hasil

Urinalisis yang terbaik didapatkan jika dikerjakan oleh petugas yang terampil pada urine segar (dikerjakan sekitar 30 - 60 menit sesudah urine ditampung) dan dilakukan kombinasi pemeriksaan esterase leukosit, nitrit dan pemeriksaan leukosit urine serta pewarnaan Gram dengan menggunakan mikroskop.

Pemeriksaan sedimen urine menggunakan urine segar dengan jumlah volume spesimen $10 \mathrm{~mL}$, memiliki stabilitas pada suhu kamar yaitu selama 1 jam. Jika urine didiamkan lama maka bakteri akan berkembangbiak banyak, sehingga dapat menguraikan $\mathrm{NH}_{3}$ (amoniak) yang bersifat basa (Soebrata, 2008). Pada kondisi basa, $\mathrm{pH}$ dalam urine akan meningkat. Hal ini dapat mempengaruhi komponen sedimen dalam urine menjadi cepat lisis sehingga jumlahnya akan berkurang (Zahrin, 2014).

Berdasarkan latar belakang tersebut, maka penulis tertarik untuk melakukan penelitian tentang "Perbandingan Pemeriksaan Leukosit Urine Segar dengan Setelah 2 jam Di Suhu Kamar".

METODE PENELITIAN

Jenis Penelitian

Desain penelitian yang digunakan adalah desain deskriptif observasional

\section{Sampel}

Sampel urine yang digunakan yaitu urine sebanyak 20 sampel.

Alat dan Bahan

Alat yang digunakan dalam penelitian ini yaitu wadah penampung urine (bermulut lebar dan tertutup rapat, harus bersih dan kering, wadah diberi label : nama, nomor dan tanggal), cover glass, objek glass, tabung reaksi, rak tabung reaksi, mikroskop, sentrifuge, tabung sentrifuge, mikropipet, tissue. Bahan yang digunakan yaitu sampel urine.

\section{Prosedur Penelitian}

\section{Cara mendapatkan sampel urine}

Siapkan alat yang diperlukan yang dibutuhkan oleh pasien untuk menampung urine (pot urine, dan tissue). Beri label identitas pada pot urine. Lakukan komunikasi yang baik dan santun untuk meminta pasien berkemih dan ditampung 
dalam pot yang sudah diberikan.

Tunggu hingga pasien selesai berkemih, kemudian anjurkan pasien untuk meletakkan urine pada meja sampel yang sudah disediakan dan menungu hasil pemeriksaan di ruang tunggu. Sampel siap untuk diperiksa (Soebrata, 2008).

\section{Cara Pemeriksaan Makroskopis}

Pemeriksaan secara makroskopis yaitu pemeriksaan sampel urine dengan melihat warna urine, bau, dan kejernihan.

\section{Cara Pemeriksaan Mikroskopis}

Cara pemeriksaan mikroskopis sedimen urine yaitu, perhatikan identitas sampel. Homogenkan terlebih dahulu sampel. Sampel tersebut dibagi pada 2 tabung kemudian dilakukan sentrifuge urine selama 5 menit dengan kecepatan 1500-2000rpm. Setelah itu buang bagian atas urine sehingga urine tersisa 0,5-1 mL. Kemudian kocok tabung untuk mensuspensikan sedimen. Pipet $20 \mu 1$ sampel tersebut kemudian teteskan pada objek glass dan tutup dengan cover glass. Diperiksa sedimen dibawah mikroskop dengan lensa objektif 40x untuk Lapangan Pandang Besar (LPB) ( Permenkes Nomor 43 Tahun 2013).

\section{Analisis Data}

Analisa Bivariat menggunakan uji Wilxocon. Pengolahan data ini diinterpretasikan dengan menggunakan nilai probabilitas ( $p$ value) dengan kriteria bila table $2 \times 2$ mencapai nilai $<0,05$ maka hasil tersebut dianggap bermakna.

\section{HASIL}

Tabel 1. Karakteristik dan Hasil Pemeriksaan Sedimen Urine Leukosit Urine Segar dan Urine Setelah 2 Jam

\begin{tabular}{lll}
$\begin{array}{l}\text { Nomor } \\
\text { Sampel }\end{array}$ & $\begin{array}{l}\text { Leukosit } \\
\text { Urine Segar }\end{array}$ & $\begin{array}{l}\text { Leukosit Urine } \\
\text { Setelah 2 Jam }\end{array}$ \\
\hline S1 & 5-10/LP & 3-5/LP \\
\hline S2 & 4-5/LP & 0-1/LP \\
\hline S3 & 6-8/LP & 0-1/LP \\
\hline S4 & 5-6/LP & 0-1/LP \\
\hline S5 & 8-10/LP & 1-2/LP \\
\hline S6 & 25-30/LP & 10-15/LP \\
\hline S7 & 20-25/LP & 8-10/LP \\
\hline S8 & 5-8/LP & 3-8/LP \\
\hline S9 & 10-16/LP & 5-10/LP \\
\hline S10 & 10-15/LP & 5-6/LP \\
\hline S11 & 6-8/LP & 4-6/LP \\
\hline S12 & 10-15/LP & 5-10/LP \\
\hline S13 & 6-8/LP & 3-5/LP \\
\hline S14 & 4-8/LP & 0-2/LP \\
\hline S15 & 5-6/LP & 0-2/LP \\
\hline S16 & 15-20/LP & 12-15/LP \\
\hline S17 & 18-20/LP & 8-10/LP \\
\hline S18 & 6-8/LP & 3-5/LP \\
\hline S19 & 6-8/LP & 2-4/LP \\
S20 & 3-5/LP & $0-1 / L P$ \\
\hline
\end{tabular}

Purwaningsih, N. V. dan Rahma W. 2018. Perbandingan Pemeriksaan Leukosit Urine Segar Dengan Setelah 2 Jam Di Suhu Kamar. Surabaya : The Journal of Muhamadiyah Medical Laboratory Technologist. Vol: 1, No.2 (103-109). 
Tabel 2. Perbandingan Hasil Pemeriksaan Leukosit antara Urine Segar dengan Setelah 2 Jam

\begin{tabular}{llll} 
Variabel & $\begin{array}{l}\text { Urine } \\
\text { Segar }\end{array}$ & $\begin{array}{l}\text { Urine } \\
\text { Setelah } \\
\text { 2 Jam }\end{array}$ & $\begin{array}{l}\text { Nilai } \\
\text { (value) }\end{array}$ \\
\hline Median & 6,00 & 3,00 & 0,001
\end{tabular}

(IQR) (5) (5)

Dari data Uji Wilcoxon diperoleh p-value $<0,001(>0,05)$.

\section{PEMBAHASAN}

Berdasarkan hasil penelitian terhadap pemeriksaan leukosit urine segar dengan setelah 2 jam suhu kamar dengan 20 sampel didapatkan p-value $<0,001(>0,05)$ berarti ada perbedaan hasil pemeriksaan leukosit urine segar dibandingkan setelah 2 jam di suhu kamar.

Penelitian ini sejalan dengan hasil penelitian Zahrin (2014) menyatakan bahwa ada pengaruh secara parsial terhadap penundaan pemeriksaan eritrosit pada sedimen urine. Urine memiliki stabilitas pada suhu kamar yaitu selama 1 jam, jika urine didiamkan lama maka bakteri akan berkembang biak, sehingga dapat menguraikan $\mathrm{NH}_{3}$ (amoniak) yang bersifat basa. Pada kondisi basa, $\mathrm{pH}$ dalam urine akan meningkat. Hal ini dapat mempengaruhi komponen sedimen dalam urine menjadi cepat lisis sehingga jumlahnya akan berkurang (Zahrin, 2014).

$$
\text { Panduan }
$$

Praktek

Laboratorium yang Benar Depkes Republik Indonesia menyatakan bahwa, faktor - faktor yang mempengaruhi stabilitas spesimen antara lain urine terkontaminasi oleh bahan kimia, terjadi metabolisme sel - sel hidup pada spesimen, terjadi penguapan.

Hal ini juga didukung oleh penelitian Rosita (2009), bahwa pengaruh penundaan waktu terhadap Urinalisis memberikan memberikan informasi tentang disfungsi ginjal. Bahan tes yang terbaik adalah urine segar kurang dari 1 jam setelah dikeluarkan. Penundaan antara berkemih dan Urinalisis akan mengurangi validitas hasil, analisis harus dilakukan tidak lebih dari 4 jam setelah pengambilan sampel. Apabila dilakukan penundaan tes dalam 4 jam maka disimpan dalam lemari es pada suhu $2-4^{\circ} \mathrm{C}$. Urine yang dibiarkan dalam waktu lama pada suhu kamar akan menyebabkan perubahan pada urine. Unsur-unsur berbentuk di urine (sedimen) mulai mengalami kerusakan dalam 2 jam. 
Leukosit urine merupakan

salah satu pemeriksaan penunjang pada penyakit ginjal, dikatakan normal jika terdapat 2-3/LPB leukosit di dalam urine. Suatu keadaan terdapatnya leukosit dalam urine yang melebihi nilai normal disebut leukosituria. Leukosituria merupakan salah satu tanda adanya peradangan pada saluran kemih (mencakup ginjal, ureter, kandung kemih, dan uretra), dikatakan bermakna bila ditemukan >5 leukosit/LPB pada sedimen urine. Leukosituria dapat terjadi pada keadaan infeksi maupun inflamasi saluran kemih, seperti glomerulonefritis, pielonefritits, sistitis, uretritis, nefrolitiasis, urolitiasis, dll. Jika bakteri tidak ditemukan (disebut leukosituria steril) maka harus dipertimbangkan adanya penyebab lain seperti tuberkulosis saluran ginjal, kanker dan saluran kemih (Hapsari, 2012).

\section{SIMPULAN}

Berdasarkan penelitian yang
telah dilakukan maka dapat
disimpulkan bahwa ada perbedaan
hasil leukosit urine segar lebih baik

dibandingkan urine setelah 2 jam di suhu kamar.

\section{DAFTAR PUSTAKA}

Depkes., 2004. Petunjuk Pelaksanaan Pemantapan Mutu Internal Laboratorium Kesehatan. Jakarta : Departemen Kesehatan RI

Hapsari, P., 2012. Perbedaan kejadian Leukosituri antara Penderita Penyakit Ginjal Kronik Stadium $V$ dengan Diabetes Melitus dan Tanpa Diabetes Melitus. Karya Tulis Ilmiah. Universitas Diponegoro.

Hardjoeno, H dan Fitriani. 2007. Substansi Dan Cairan Tubuh. Lembaga Penerbitan Universitas Hasanuddin.

Hardjoeno, Yetty Fauza, Benny Rusli. 2006. Interpretasi hasil laboratorium diagnostik. Penerbit Buku Universitas Hasanuddin. Makassar.

Peraturan Menteri Kesehatan Republik Indonesia Nomor 43 Tahun 2013

Peraturan Menteri Kesehatan Republik Indonesia Nomor 9 Tahun 2014

Rosalita, L. Pengaruh Penundaan Waktu Terhadap Hasil Urinalisis. Departemen Patologi Klinik fakultas Kedokteran Universitas Islam Indonesia Yogyakarta. 
Soebrata, G., 2008. Penuntun

Laboratorium Klinik. Jakarta :

Dian Rakyat

Zahrin, I., 2014. Pengaruh

Penundaan dan Pemeriksaan

Serta Suhu Penyimpanan

Terhadap Ph dan Eritrosit Urine.

Karya Tulis Ilmiah. STIKes Wira

Medika Bali. 